\title{
Huge rhabdomyoma attached to the apex of the left ventricle
}

\section{Sol ventrikül apeksine yapışmış büyük rabdomiyom}

\author{
Taliha Öner, (1) Fatih Özdemir, (ㄷ) Mehmet Dedemoğlu, (1) Can Vuran, (ㄷ) Mehmet Karacan
}

Department of Pediatrics, University of Health Sciences, Ümraniye Training and Research Hospital, İstanbul, Turkey

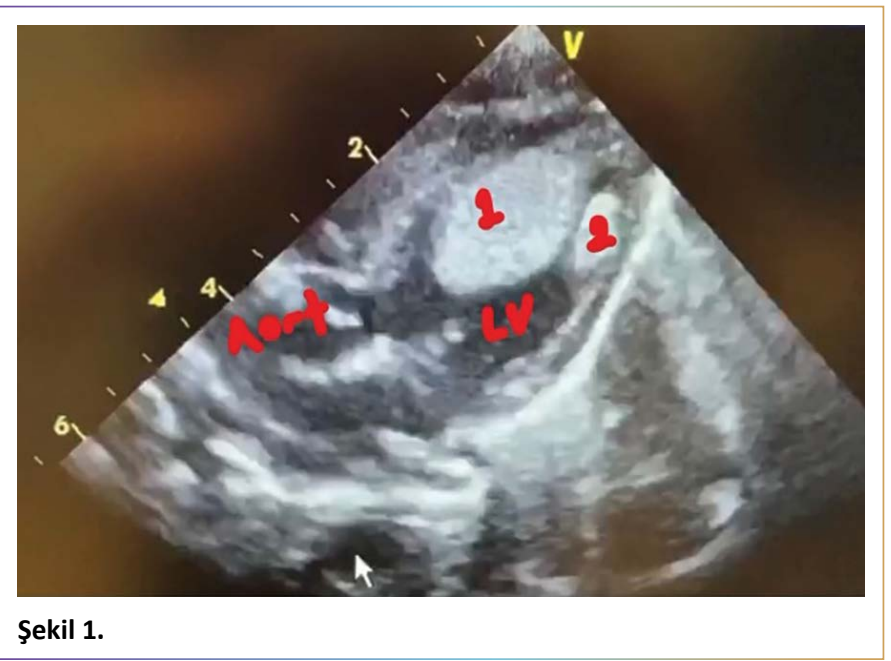

1 günlük 2800 gram doğmuş, fetal dönemden itibaren rabdomyom tanısı ile takipli hasta idi. Postnatal ekokardiyografisinde sol ventrikül içerisinde apekse yapışan çok büyük rabdomyomu ve sol ventrikül serbest duvara yapışmış küçük rabdomyomu mevcuttu. Hastanın rabdomyomu cerrahi olarak çıkarıldı. Operasyon sonrası 1. günde ventilatör desteğinden çıkarılan hasta 3 . gün servise indirildi ve 5. günde taburcu edildi.

Cite this article as: Öner T, Özdemir F, Dedemoğlu M, Vuran C, Karacan M. Huge rhabdomyoma attached to the apex of the left ventricle. Jour Umraniye Pediatr 2021;1(1):28.

ORCID ID

T.Ö.: 0000-0002-3581-8510; F.Ö.: 0000-0002-0409-3588; M.D.: 0000-0002-5532-4307; C.V.: 0000-0002-8790-6205; M.K.: 0000-0002-4375-2881

Sağıık Bilimleri Üniversitesi Ümraniye Eğitim ve Araştırma Hastanesi, Çocuk Sağlığı ve Hastalıkları Kliniği, İstanbul, Türkiye

Received (Başvuru tarihi): 25.12.2020 Accepted (Kabul tarihi): 25.12.2020 Online (Online yayınlanma tarihi): 15.01.2021

Correspondence (iletişim): Dr. Taliha Öner. Sağlık Bilimleri Üniversitesi, Ümraniye Eğitim ve Araştırma Hastanesi,

Çocuk Sağlığı ve Hastalıkları Kliniği, İstanbul, Türkiye.

Phone (Tel): +90 5056576535 e-mail (e-posta): talihaoner@yahoo.com

(c) Copyright 2021 by Istanbul Provincial Directorate of Health - Available online at www.umraniyepediatri.com 